\title{
Divergent effects of acute exercise and endurance training on UCP3 expression
}

Citation for published version (APA):

Hesselink, M. K. C., Schrauwen, P., Holloszy, J. O., \& Jones, T. E. (2003). Divergent effects of acute exercise and endurance training on UCP3 expression. American Journal of Physiology : Endocrinology and Metabolism, 284(2), E449-E450. https://doi.org/10.1152/ajpendo.00417.2002

Document status and date:

Published: 01/01/2003

DOI:

10.1152/ajpendo.00417.2002

Document Version:

Publisher's PDF, also known as Version of record

Document license:

Taverne

Please check the document version of this publication:

- A submitted manuscript is the version of the article upon submission and before peer-review. There can be important differences between the submitted version and the official published version of record.

People interested in the research are advised to contact the author for the final version of the publication, or visit the DOI to the publisher's website.

- The final author version and the galley proof are versions of the publication after peer review.

- The final published version features the final layout of the paper including the volume, issue and page numbers.

Link to publication

\footnotetext{
General rights rights.

- You may freely distribute the URL identifying the publication in the public portal. please follow below link for the End User Agreement:

www.umlib.nl/taverne-license

Take down policy

If you believe that this document breaches copyright please contact us at:

repository@maastrichtuniversity.nl

providing details and we will investigate your claim.
}

Copyright and moral rights for the publications made accessible in the public portal are retained by the authors and/or other copyright owners and it is a condition of accessing publications that users recognise and abide by the legal requirements associated with these

- Users may download and print one copy of any publication from the public portal for the purpose of private study or research.

- You may not further distribute the material or use it for any profit-making activity or commercial gain

If the publication is distributed under the terms of Article $25 \mathrm{fa}$ of the Dutch Copyright Act, indicated by the "Taverne" license above, 
The following is the abstract of the article discussed in the subsequent letter:

Jones, Terry E., Keith Baar, Edward Ojuka, May Chen, and John O. Holloszy. Exercise induces an increase in muscle UCP3 as a component of the increase in mitochondrial biogenesis. Am J Physiol Endocrinol Metab 284: E96-E101, 2003. First published September 17, 2002; 10.1152/ajpendo.00316.2002.-Previous studies have indicated that exercise acutely induces large increases in uncoupling protein-3 (UCP3) in skeletal muscle, whereas endurance training results in marked decreases in muscle UCP3. Because UCP3 expression appears to be regulated by the same mechanism as other mitochondrial constituents, it seemed unlikely that exercise would result in such large and divergent changes in mitochondrial composition. The purpose of this study was to test the hypothesis that major changes in UCP3 protein concentration do not occur independently of mitochondrial biogenesis and that UCP3 increases as a component of the exercise-induced increase in mitochondria. We found a large increase in UCP3 mRNA immediately and $3 \mathrm{~h}$ after a bout of swimming. UCP3 protein concentration was increased $\sim 35 \% 18 \mathrm{~h}$ after a single exercise bout, $\sim 63 \%$ after 3 days, and $\sim 84 \%$ after 10 days of exercise. These increases in UCP3 roughly paralleled those of other mitochondrial marker proteins. Our results are consistent with the interpretation that endurance exercise induces an adaptive increase in mitochondria that have a normal content of UCP3.

\section{Divergent effects of acute exercise and endurance training on UCP3 expression}

To the Editor: The primary physiological function of mitochondrial uncoupling protein-3 (UCP3) is not yet known. Because of its homology with UCP1, it has been hypothesized that UCP3 is involved in the regulation of energy expenditure in skeletal muscle. Therefore, the effect of exercise and endurance training on UCP3 expression has been extensively studied. These studies unequivocally show that UCP3 mRNA expression is transiently upregulated after an acute bout of exercise $(4-6,14)$, an effect largely accounted for by increased free fatty acid levels (10). Recently, Jones et al. (3) confirmed this finding, showing that, in rats, UCP3 mRNA was increased acutely and $3 \mathrm{~h}$ after a single exercise bout. Jones et al. also reported a marked $\sim 63$ and $\sim 84 \%$ increase in UCP3 protein after 3 and 10 days of endurance training, respectively. These findings have led the authors to conclude that "endurance exercise results in an increase in UCP3 protein in skeletal muscle as a component of the exercise-induced increase in mi- tochondrial biogenesis" (3). In this case, however, their conclusion is in contrast with the generally observed finding of decreased UCP3 mRNA and protein levels following endurance training $(1,7,8$, 11-14). For example, Boss et al. (1) showed downregulation of UCP3 mRNA after 8 wk of endurance training in rats (1). In humans, these findings are extended to the protein level, showing decreased UCP3 protein content in trained athletes (7) and after training (11). What can be the reason for the discrepancy between these studies and the conclusion of Jones et al.? Jones et al. show that UCP3 is increased by $\sim 35, \sim 64$, and $\sim 84 \%$ with a concerted upregulation of cytochrome $c$ and citrate synthase (marker proteins for mitochondrial density). Thus, if the upregulation of UCP3 related to the actual mitochondrial density, the more obvious conclusion would have been that the 10-day training program did not affect mitochondrial UCP3 content. Papers showing declined UCP3 protein levels following training have a cross-sectional (7) rather than a longitudinal design. In longitudinal designs, declined UCP3 levels have been reported after a 14-day training period (9) or longer (11). At present, there is paucity of data about the precise triggers, conditions, and time frame related to training-induced downregulation of UCP3. It therefore cannot be ruled out that the training intervention applied by Jones et al. is of insufficient duration to detect a training-induced decline in UCP3. Moreover, the divergent effect of acute exercise and training on UCP3 mRNA expression perfectly illustrates the importance of the time frame of sampling. Tsuboyama-Kasaoka et al. (14) showed profound upregulation of UCP3 mRNA $3 \mathrm{~h}$ postexercise and a return to pretraining levels within $22 \mathrm{~h}$, and reduced levels were recorded $44 \mathrm{~h}$ postexercise. In the study by Jones et al., increased UCP3 protein with undetectably low mRNA levels (i.e., very low transcriptional activity) was reported $18 \mathrm{~h}$ after a single exercise session. It is therefore conceivable that the protein levels will decrease after the 18 -h period. Because Jones et al. sampled muscles 18-20 $\mathrm{h}$ postexercise, it is likely that the mRNA data, and possibly protein levels reported, are biased by the remnant effect of the final exercise bout.

In summary, we think that the paper by Jones et al. (3) is compatible with previous studies. The lack of increase in UCP3 when expressed per mitochondria and the undetectably low mRNA levels $18 \mathrm{~h}$ postexercise make it feasible that, in the long term (depending on the UCP3 half-life time), decreased 
UCP3 protein levels will be detected after endurance training. Furthermore, this study again stresses the importance of considering the remnant effect of the final exercise bout when studying the effects of endurance training. Indeed, in previous papers from the same laboratory in which the same protocol was used, it was shown that the training-induced increase in GLUT4 was almost completely abolished within $40 \mathrm{~h}$ postexercise (2).

\section{REFERENCES}

1. Boss O, Samec S, Desplanches D, Mayet MH, Seydoux J, Muzzin P, and Giacobino JP. Effect of endurance training on mRNA expression of uncoupling proteins 1,2 , and 3 in the rat. FASEB J 12: 335-339, 1998.

2. Host HH, Hansen PA, Nolte LA, Chen MM, and Holloszy JO. Rapid reversal of adaptive increases in muscle GLUT-4 and glucose transport capacity after training cessation. $J$ Appl Physiol 84: 798-802, 1998.

3. Jones TE, Baar K, Ojuka E, Chen M, and Holloszy JO. Exercise induces an increase in muscle UCP3 as a component of the increase in mitochondrial biogenesis. Am J Physiol Endocrinol Metab 284: E96-E101, 2002.

4. Pedersen SB, Lund S, Buhl ES, and Richelsen B. Insulin and contraction directly stimulate UCP2 and UCP3 mRNA expression in rat skeletal muscle in vitro. Biochem Biophys Res Commun 283: 19-25, 2001.

5. Pilegaard H, Keller C, Steensberg A, Helge JW, Pedersen BK, Saltin B, and Neufer PD. Influence of pre-exercise muscle glycogen content on exercise-induced transcriptional regulation of metabolic genes. J Physiol 541: 261-271, 2002.

6. Pilegaard H, Ordway GA, Saltin B, and Neufer PD. Transcriptional regulation of gene expression in human skeletal muscle during recovery from exercise. Am $J$ Physiol Endocrinol Metab 279: E806-E814, 2000.

7. Russell A, Wadley G, Hesselink MKC, Schaart G, Lo SK, Leger B, Garnham A, Kornips E, Cameron-Smith D, Giacobino JP, Muzzin P, Snow R, and Schrauwen P. UCP3 protein expression is lower in type 1, IIa and IIx muscle fiber types of endurance trained compared to untrained subjects. Pflügers Arch [Online], http://link.springer-ny.com/link/ service/journals/00424/contents/02/00943/paper/500424-0020943-5ch110.html

8. Russell A, Wadley G, Snow R, Giacobino JP, Muzzin P, Garnham A, and Cameron-Smith D. Slow component of $\dot{\mathrm{VO}}_{2}$ kinetics: the effect of training status, fibre type, UCP3 mRNA and citrate synthase activity. Int J Obes Relat Metab Disord 26 : 157-164, 2002.

9. Schrauwen $\mathbf{P}$ and Hesselink MK. Uncoupling protein 3 and physical activity; the role of UCP3 revisited. In press.

10. Schrauwen P, Hesselink MK, Vaartjes I, Kornips E, Saris WH, Giacobino JP, and Russell A. Effect of acute exercise on uncoupling protein 3 is a fat metabolism-mediated effect. Am $J$ Physiol Endocrinol Metab 282: E11-E17, 2002.

11. Schrauwen P, Saris WH, and Hesselink MK. An alternative function for human uncoupling protein 3: protection of mitochondria against accumulation of nonesterified fatty acids inside the mitochondrial matrix. FASEB $J$ 15: 2497-2502, 2001.

12. Schrauwen P, Troost FJ, Xia J, Ravussin E, and Saris WH. Skeletal muscle UCP2 and UCP3 expression in trained and untrained male subjects. Int J Obes Relat Metab Disord 23: 966-972, 1999.

13. Tonkonogi M, Krook A, Walsh B, and Sahlin K. Endurance training increases stimulation of uncoupling of skeletal muscle mitochondria in humans by non-esterified fatty acids: an uncoupling-protein-mediated effect? Biochem $J$ 351: 805810,2000
14. Tsuboyama-Kasaoka N, Tsunoda N, Maruyama K, Takahashi M, Kim H, Ikemoto S, and Ezaki O. Up-regulation of uncoupling protein 3 (UCP3) mRNA by exercise training and down-regulation of UCP3 by denervation in skeletal muscles. Biochem Biophys Res Commun 247: 498-503, 1998.

Matthijs K. C. Hesselink
Department of Movement Sciences

Patrick Schrauwen

Department of Human Biology

Nutrition and Toxicology Research Institute

Maastricht, 6200 MD Maastricht University, The Netherlands

\section{REPLY}

To the Editor: Drs. Hesselink and Schrauwen say, in their letter entitled Divergent effects of acute exercise and endurance training on UCP3 expression, that our findings show that "... if related to actual mitochondrial density, the more obvious conclusion would have been that the 10-day training program did not affect mitochondrial UCP3 content." This is exactly what we concluded: "These increases in UCP3 roughly paralleled those of other mitochondrial marker proteins. Our results are consistent with the interpretation that endurance exercise induces an adaptive increase in mitochondria that have a normal content of UCP3." So we do not understand what is meant by ". . . the more obvious conclusion would have been. ..."

Mitochondrial biogenesis is regulated and coordinated by the transcriptional coactivator PGC-1 $(3,6)$. The uncoupling proteins (UCPs) are among the mitochondrial proteins that increase and are incorporated into mitochondria in response to increases in PGC-1 $(3,6)$. PGC-1 protein increases in muscle in response to exercise and, likely, mediates the adaptive increase in mitochondria in skeletal muscle (1). In addition, the peroxisome proliferator-activated receptor- $\alpha$ (which is coactivated by PGC-1) is activated by fatty acids and mediates an increase in the mitochondrial enzymes involved in the oxidation of fatty acids $(2,5)$. Apparently, an increase in UCP3 is a component of this response (4). Each bout of exercise induces increases in PGC-1 expression and in plasma fatty acid concentration that result over time in an increase in muscle mitochondria. In this context, the suggestion that mitochondria undergo an enormous change in mitochondrial composition, with large increases in the enzymes involved in carbohydrate and fat oxidation but a large decrease in UCP3 protein, does not seem plausible.

\section{REFERENCES}

1. Baar K, Wende AR, Jones TE, Marison M, Nolte LA, Chen M, Kelly DP, and Holloszy JO. Adaptations of skeletal muscle to exercise: rapid increase in the transcriptional coactivator PGC-1. FASEB J 16: 1879-1886, 2002.

2. Gulick T, Cresci S, Caira T, Moore DD, and Kelly DP. The peroxisome proliferator-activated receptor regulates mitochondrial fatty acid oxidative enzyme gene expression. Proc Natl Acad Sci USA 91: 11012-11016, 1994. 
3. Puigserver $\mathbf{P}$, Wu Z, Park $\mathbf{C W}$, Graves $\mathbf{R}$, Wright $\mathbf{M}$, and Spiegelman BM. A cold-inducible coactivator of nuclear receptors linked to adaptive thermogenesis. Cell 92: 829-839, 1998.

4. Schrauwen P, Hoppeler H, Billeter R, Bakker AHF, and Pendergast DR. Fiber type dependent upregulation of human skeletal muscle UCP2 and UCP3 mRNA expression by high-fat diet. Int J Obes Relat Metab Disord 25: 449-456, 2001.

5. Vega R, Huss JM, and Kelly DP. The coactivator PGC-1 cooperates with peroxisome proliferator-activated receptor $\alpha$ in transcriptional control of nuclear genes encoding mitochondrial fatty acid oxidation enzymes. Mol Cell Biol 20: 1868-1876, 2000.
6. Wu Z, Puigserver P, Andersson U, Zhang C, Adelmant G, Mootha V, Troy A, Cinti S, Lowell B, Scarpulla RC, and Spiegelman BM. Mechanisms controlling mitochondrial biogenesis and respiration through the thermogenic coactivator PGC-1. Cell 98: 115-124, 1999.

John O. Holloszy and Terry E. Jones Department of Internal Medicine Washington University School of Medicine St. Louis, MO 63110

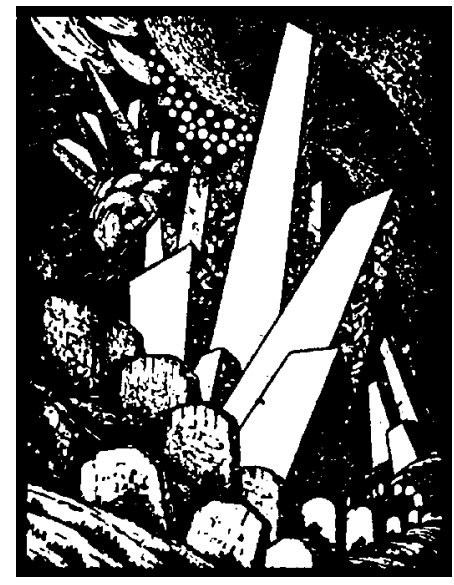

